\title{
Modifications Influencing Widal Test Reactivity in a Novel Microplate Assay
}

\author{
ADEL ALMOGREN ${ }^{1}$, ZAHID SHAKOOR ${ }^{1 \star}$, MUSTAFA HUSSEIN ADAM ${ }^{1}$, \\ MOHAMMAD OSMAN GADELRAB ${ }^{1}$ and HASSAN ABDULAZIZ MUSA ${ }^{2}$ \\ ${ }^{1}$ Department of Pathology, King Khalid University Hospital, King Saud University, Kingdom of Saudi Arabia \\ ${ }^{2}$ Faculty of Medicine, National Rabat University, Khartoum, Sudan
}

Received 2 November 2011, revised 5 April 2012, accepted 9 April 2012

\begin{abstract}
Reliability of the Widal tube agglutination test has been the subject of many controversies over the years. This study was performed to assess the effect of certain modifications on the performance of Widal test in a novel microplate assay. Sera from 37 patients (21 males; 16 females) (mean age $28 \pm 7$ years) were tested in the Immunology Unit at King Khalid University Hospital, Riyadh. Among them were 26 patients with suspected typhoid fever and 11 had bacteriologically confirmed diagnosis of Salmonella infection. The modifications included either the use of $0.5 \%$ bovine serum albumin (BSA), absorption of sera with sheep red blood cells (SRBC) or heat inactivation of sera. Compared with Widal tube agglutination test, microplate assay with SRBC absorption of the sera from patients with suspected typhoid fever was not only associated with enhancement of detection titers for both $\mathrm{H}(\mathrm{p} \leq 0.001)$ and $\mathrm{O}(\mathrm{p} \leq 0.005)$ Salmonella agglutinins but also the percentage of reactivity. The presence of BSA augmented detection titers for Salmonella H agglutinins $(\mathrm{p} \leq 0.02)$ only. Heat inactivation of sera however was found to be associated with reduction in the detectable titers for both $\mathrm{H}(\mathrm{p} \leq 0.03)$ and $\mathrm{O}(\mathrm{p} \leq 0.01)$ agglutinins. Increased titers of Salmonella agglutinins were also evident in 11 patients with confirmed diagnosis of Salmonella infection. The novel microplate agglutination assay using the SRBC absorption was associated with enhancement in Widal test reactivity and appears to be a useful alternative for the diagnosis of Salmonella infection.
\end{abstract}

Ke y words: Salmonella typhi, microplate agglutination assay, Salmonella agglutinins, Widal tube agglutination test

\section{Introduction}

The diagnosis of typhoid fever is usually made by detection of Salmonella typhi organisms in blood that is less sensitive than isolation of the organism from bone marrow which is considered as the gold standard (Farooqui et al., 1991). Bone marrow aspiration is an invasive procedure and requires skilled laboratory personnel often not available at primary healthcare facilities (Wain et al., 2008). Similarly in the developing countries where typhoid fever is endemic a relatively small number of laboratories at primary healthcare centres are equiped with the culture facilities requried for isolation of Salmonella organisms and the diagnosis of typhoid fever only on clinical evidence remains a problem (Parry et al., 1999; Pang et al., 1983; Choo et al., 1993; Saha et al., 1996). Detection of circulating antibodies against Salmonella typhi in serum is therefore useful in the diagnosis of typhoid fever. Rising titers over time or a single high titer of Salmonella agglutin- nins have been regarded as diagnostically significant (Wain et al., 2008). However, there are several factors which tend to obscure the serological picture; the most important is the sharing of antigens that stimulate antibody production by a large number of organisms from the same genus or from other related organisms yeliding false positive results (Jindal et al., 1992; Chart et al., 1994a; Chart et al., 1994b).

A number of attempts have been made in the past to develop a reliable serological technique for the diagnosis of typhoid fever (Duthie and French, 1990). These include the Widal agglutination test, haemagglutination test, enzyme-linked immunosorbent assay, immunoelectrophoresis and polymerase chain reaction test (Rai et al., 1989; Barrett et al., 1983; Nardiello et al., 1984; Verdugo-Rodriguez et al., 1993; Jesudason et al., 1998; Chart et al., 1997; Sharma et al., 1997). None of these tests could be adopted for routine use on account of various reasons whereby the Widal tube agglutination test remained a simple, inexpensive, semiquantitative

* Corresponding author: Z. Shakoor, Department of Pathology, King Khalid University Hospital, King Saud University, Riyadh 11461, Kingdom of Saudi Arabia; phone: 00966-1-4671299; fax: 00966-1-4671842; e-mail: shakoor_zahid@yahoo.com 
agglutination test for detecting Salmonella agglutinins (Parry et al., 1999; Choo et al., 1993; Saha et al., 1996; Coovadia et al., 1986).

Despite being used most frequently the specificity and sensitivity of the Widal test has been debated for many years, especially in the endemic areas where typhoid fever co-exists with non-typhoid febrile illnesses such as malaria and tuberculosis (Rai et al., 1989; Ghosh et al., 2001; Bakr et al., 2011; Keddy et al., 2011). Because of its limited diagnostic capability (Omuse et al., 2010) several modifications of the Widal test such as the slide agglutination test, (Hoffman et al., 1986) plate micro-agglutination test (Pang et al., 1983; Clegg et al., 1994; Barsoum and Awad, 1972), use of 2-mercaptoethanol for the detection of IgM (Jindal et al., 1992) and Salmonella para A, para B and Escherichia coli absorption (Rai et al., 1989) have been investigated but none of these could gain a reasonable acceptance. The need for a tangible test for the diagnosis of Salmonella infection therefore remains (Baker et al., 2010) and this study examines the effect of certain modifications on the performance of Widal test.

\section{Experimental}

\section{Materials and Methods}

Study population. A total of 37 patients including 21 males and 16 females with the mean age of $28 \pm 7$ years were included in the study. This group of patients comprised of 26 patients with a febrile illness with clinical suspicion of typhoid fever where the treating physician did not request bacterial cultures for isolation of the Salmonella organism. The remaining 11 patients had a definitive diagnosis of typhoid fever based on the isolation of Salmonella organisms either from blood or stool specimens. The diagnostic titers for $\mathrm{H}$ and $\mathrm{O}$ agglutinins were either equal to or greater than 1:160 and 1:80, respectively. Means were compared using Student $\mathbf{t}$ test and $\mathrm{p} \leq 0.05$ was considered significant.

Blood sample collection. $3 \mathrm{ml}$ of venous blood was collected by venipuncture and serum was obtained by allowing the blood to clot at the room temperature. A $0.5 \mathrm{ml}$ aliquot was used for Widal tube agglutination and the rest of the serum sample was stored at $-20^{\circ} \mathrm{C}$ until use.

Determination of optimal concentration of BSA. The optimal concentration of BSA was determined by checkerboard titration. Various concentrations of BSA in normal saline ranging from $0.1 \%$ to $5 \%$ were tested and $0.5 \%$ BSA in normal saline was shown to perform best in terms of interpretation of the results and reproducibility.
SRBC absorption. Commercially prepared 10\% non-sensitized sheep erythrocytes (Carter Wallace Inc, USA) were used for absorption. To $190 \mu$ l of absorbent cells in a test tube $10 \mu \mathrm{l}$ of undiluted serum sample was added to obtain a serum dilution of 1:20. The contents were mixed gently using a microplate shaker and incubated at room temperature for one hour and then centrifuged at $3000 \mathrm{rpm}$ for 10 minutes. Supernatant was collected and used for microplate agglutination assay.

Heat inactivation of sera. Serum samples were placed in a water bath at $56^{\circ} \mathrm{C}$ for 30 minutes and then cooled immediately in running tap water prior to be used in the microplate agglutination assay.

Microplate agglutination assay. $50 \mu \mathrm{l}$ of $0.5 \%$ BSA in normal saline was dispensed in all the wells of a U-type micro-titer plate. In the first well of each row $50 \mu \mathrm{l}$ of serum sample was added and double dilutions were made along the rows up to a final dilution of 1:20480. Aliquots of $50 \mu \mathrm{L}$ each from 1:100 diluted homogenous Salmonella typhi suspensions (Murex, $\mathrm{UK}$ ) for $\mathrm{H}$ and $\mathrm{O}$ antigens were then added to the respective wells. The microplate was sealed with a plastic cover, the contents were mixed by gentle shaking and this was followed by incubation at $37^{\circ} \mathrm{C}$ for 18 hours. After incubation the seal was removed from the plate and the agglutination was read on a Microtitre mirror. A positive reaction was indicated by a smooth or irregular mat shape settlement at the bottom of each well in the microtitre plate, whereas the settling of antigen to a button shape was interpreted as a negative reaction. The titer was determined as the last dilution of serum sample showing a mat formation.

Widal tube agglutination test. The standard Widal tube agglutination test was performed using a commercial kit (Murex Biotech Limited, UK) in accordance with the instructions of the manufacturers. Briefly, serum dilutions were made for each antigen to be tested using saline. One drop of bacterial suspension was added to each tube, the contents were mixed and incubated at $50^{\circ} \mathrm{C}$ for four and two hours for $\mathrm{O}$ and $\mathrm{H}$ suspensions respectively and agglutination was observed at the end of incubation.

\section{Results}

Table I shows comparison of results for detection of antibodies against $\mathrm{H}$ and $\mathrm{O}$ Salmonella antigens using the Widal tube test and the modified microplate agglutination assays for the 26 patients suspected to be suffering from Salmonella infection. Widal tube agglutination test detected $\mathrm{H}$ and $\mathrm{O}$ Salmonella agglutinins in 17 and 22 patients respectively. Microplate assay using $0.5 \% \mathrm{BSA}$ as a blocking agent enhanced the level of detection of $\mathrm{H}$ and $\mathrm{O}$ Salmonella agglutinins but sta- 
Table I

Comparison of Widal tube agglutination test with modified microplate agglutination assay in patients suspected to have typhoid fever

\begin{tabular}{|c|c|c|c|c|c|c|c|c|}
\hline \multirow{2}{*}{$\begin{array}{c}\text { S. } \\
\text { No. }\end{array}$} & \multicolumn{2}{|c|}{$\begin{array}{c}\text { Widal } \\
\text { Tube test }\end{array}$} & \multicolumn{2}{c|}{$\begin{array}{c}\text { Microplate } \\
\text { Agglutination } \\
\text { with 0.5\% BSA }\end{array}$} & \multicolumn{2}{c|}{$\begin{array}{c}\text { Microplate } \\
\text { Agglutination } \\
\text { SRBC absorption }\end{array}$} & \multicolumn{2}{c|}{$\begin{array}{c}\text { Microplate } \\
\text { Agglutination } \\
\text { Heat inactivation }\end{array}$} \\
\cline { 2 - 10 } & H titer & O titer & H titer & O titer & H titer & O titer & H titer & O titer \\
\hline 1 & 40 & 80 & 80 & 160 & 320 & 320 & - & - \\
\hline 2 & 320 & 40 & 40 & 40 & 5120 & 80 & - & - \\
\hline 3 & - & 80 & 80 & 80 & 40 & 160 & - & - \\
\hline 4 & - & 80 & 80 & 80 & 80 & 160 & - & - \\
\hline 5 & - & 80 & 80 & 80 & 80 & 160 & - & - \\
\hline 6 & 320 & 40 & 40 & 80 & 1280 & 160 & - & - \\
\hline 7 & - & 80 & 80 & 80 & 40 & 80 & 160 & - \\
\hline 8 & 40 & 160 & 160 & 160 & 320 & 160 & - & - \\
\hline 9 & - & 160 & 160 & 160 & 80 & 640 & - & 80 \\
\hline 10 & 40 & 80 & 80 & 80 & 160 & 320 & - & - \\
\hline 11 & - & 80 & 80 & 80 & - & 320 & - & - \\
\hline 12 & 80 & 80 & 80 & 320 & 320 & 640 & - & 80 \\
\hline 13 & 80 & 80 & 80 & 160 & 320 & 320 & - & - \\
\hline 14 & 160 & 320 & 320 & 320 & 640 & 320 & - & 160 \\
\hline 15 & 320 & 320 & 320 & 320 & 1280 & 640 & 160 & 320 \\
\hline 16 & 40 & 80 & 80 & 160 & 80 & 320 & 320 & 40 \\
\hline 17 & 160 & - & - & - & 640 & 80 & 40 & - \\
\hline 18 & 640 & - & - & - & 5120 & - & - & - \\
\hline 19 & - & 80 & 80 & 160 & 80 & 160 & - & - \\
\hline 20 & 80 & 40 & 40 & 40 & 320 & 40 & - & - \\
\hline 21 & 640 & - & - & 40 & 2560 & 40 & - & - \\
\hline 22 & 160 & - & - & - & 640 & - & - & - \\
\hline 23 & - & 80 & 80 & 80 & 80 & 80 & - & 80 \\
\hline 24 & - & 40 & 40 & 80 & - & 160 & 80 & - \\
\hline 25 & 320 & 80 & 80 & 80 & 2560 & 160 & - & 80 \\
\hline 26 & 320 & - & - & 40 & 1280 & 40 & 80 & - \\
\hline $\mathrm{p}$ value & & & 0.02 & $n$ & 0.005 & 0.001 & 0.03 & 0.01 \\
\hline
\end{tabular}

- represents a negative test; $\mathrm{ns}=$ not significant

Diagnostic titers for $\mathrm{H}$ and $\mathrm{O}$ agglutinins were $\geq 1: 160$ and 1:80 respectively.

tistically significant difference was observed only for $H$ agglutinins $(p \leq 0.02)$ when compared with Widal tube agglutionation test. Absorption of sera with SRBC was also associated with significant enhancement of the detectable titers for both $\mathrm{H}(\mathrm{p} \leq 0.001)$ and $\mathrm{O}(\mathrm{p} \leq 0.005)$ Salmonella antigens when compared with the titers obtained by Widal tube agglutination test. Heat inactivation on the other hand had an opposite effect where both $\mathrm{H}(\mathrm{p} \leq 0.03)$ and $\mathrm{O}(\mathrm{p} \leq 0.01)$ agglutinin detection significantly decreased when compared with the Widal tube agglutination test. Table II shows the comparison of data from 11 patients with bacteriologically confirmed Salmonella infection. All the patients were found to have high titers of antibodies against $\mathrm{O}$ and $\mathrm{H}$ Salmonella antigens when tested with the Widal tube agglu- tination test. Comparative analysis revealed further enhancement in the titers for both $\mathrm{H}(\mathrm{p} \leq 0.0002)$ and $O(p \leq 0.015)$ agglutinins when sera samples were subjected to SRBC absorption. In the presence of $0.5 \%$ BSA significant enhancement was noted only for $\mathrm{H}$ agglutinins. Table III compares data for the percentages of positive tests for Salmonella agglutinins in 26 patients suspected to have Salmonella infection. Compared to the Widal tube agglutination test, the modified microplate agglutination test detected a higher percentage of positive tests for $\mathrm{H}$ and $\mathrm{O}$ Salmonella agglutinins, either in the presence of $0.5 \%$ BSA or when the sera were absorbed with SRBCs. Heat inactivation however was associated with decreased percentage of positive tests for both $\mathrm{H}$ and $\mathrm{O}$ Salmonella agglutinins. 
Table II

Comparison of Widal tube agglutination test with modified microplate agglutination assay in patients with bacteriologically confirmed typhoid fever

\begin{tabular}{|c|c|c|c|c|r|r|r|c|}
\hline \multirow{2}{*}{$\begin{array}{c}\text { S. } \\
\text { No. }\end{array}$} & \multicolumn{2}{|c|}{$\begin{array}{c}\text { Widal } \\
\text { Tube test }\end{array}$} & \multicolumn{2}{c|}{$\begin{array}{c}\text { Microplate } \\
\text { Agglutination } \\
\text { with } 0.5 \% \text { BSA }\end{array}$} & \multicolumn{2}{c|}{$\begin{array}{c}\text { Microplate } \\
\text { Agglutination } \\
\text { SRBC absorption }\end{array}$} & \multicolumn{2}{c|}{$\begin{array}{c}\text { Microplate } \\
\text { Agglutination } \\
\text { Heat inactivation }\end{array}$} \\
\cline { 2 - 10 } & H titer & O titer & H titer & O titer & H titer & O titer & H titer & O titer \\
\hline 1 & 2560 & 160 & 5120 & 160 & 10240 & 640 & 1280 & 160 \\
\hline 2 & 320 & 160 & 640 & 320 & 5120 & 640 & 160 & 320 \\
\hline 3 & 640 & 1280 & 1280 & 1280 & 5120 & 2560 & 1280 & 640 \\
\hline 4 & 640 & 1280 & 5120 & 1280 & 10240 & 5120 & 1280 & 640 \\
\hline 5 & 320 & 320 & 1280 & 320 & 2560 & 640 & 320 & 160 \\
\hline 6 & 2560 & 320 & 5120 & 640 & 10240 & 1280 & 1280 & 320 \\
\hline 7 & 2560 & 5120 & 10240 & 5120 & 20480 & 10240 & 1280 & 2560 \\
\hline 8 & 2560 & 320 & 5120 & 640 & 20480 & 10240 & 640 & 640 \\
\hline 9 & 640 & 640 & 2560 & 1280 & 10240 & 5120 & 320 & 640 \\
\hline 10 & 640 & 640 & 1280 & 640 & 5120 & 1280 & 640 & 640 \\
\hline 11 & 1280 & 160 & 2560 & 320 & 2560 & 2560 & 640 & 320 \\
\hline $\mathrm{p}$ value & & 0.009 & $\mathrm{~ns}$ & 0.0002 & 0.01 & $\mathrm{~ns}$ & $\mathrm{~ns}$ \\
\hline
\end{tabular}

$\mathrm{ns}=$ not significant

Diagnostic titers for $\mathrm{H}$ and $\mathrm{O}$ agglutinins were $\geq 1: 160$ and 1:80 respectively

Table III

Comparison of diagnostic titers for Salmonella agglutinins between Widal tube agglutination test and modified microplate agglutination assay in 26 patients with suspected typhoid fever

\begin{tabular}{|l|c|c|}
\hline \multicolumn{1}{|c|}{ Type of test } & $\begin{array}{c}\text { Salmonella O agglutinins } \\
\text { No. (\%) }\end{array}$ & $\begin{array}{c}\text { Salmonella H agglutinins } \\
\text { No. (\%) }\end{array}$ \\
\hline Widal tube agglutination test & $17(65.3)$ & $10(38.4)$ \\
\hline Microplate agglutination test using 0.5\% BSA & $19(73)$ & $15(57.6)$ \\
\hline Microplate agglutination test with SRBC absorption & $21(80.7)$ & $16(61.5)$ \\
\hline Microplate assay with heat inactivation & $7(26.9)$ & $8(30.7)$ \\
\hline
\end{tabular}

Diagnostic titers for $\mathrm{O}$ and $\mathrm{H}$ agglutinins were $\geq 1: 80$ and 1:160 respectively.

\section{Discussion}

Using the novel microplate agglutination assay this study shows significant enhancement in the detection of titers for $\mathrm{H}$ and $\mathrm{O}$ Salmonella agglutinins both in the presence of $0.5 \%$ BSA and SRBC absorption, when compared with the results of the routine Widal tube agglutination test.

The presence of $0.5 \%$ BSA was shown to enhance the detection of Salmonella agglutinins. Since BSA as a blocking agent was used for the first time in the microplate agglutination assay, various concentrations of BSA diluted in normal saline were tested; BSA concentration of $0.5 \%$ was found to be optimal where a clear-cut well-defined and smooth settlement was obtained consistently. Since BSA is known for its ability to block vacant binding sites in microplate wells (Steinitz, 2000), this blocking action may have allowed all antigen and antibody molecules to react uniformly and could have contributed to enhancement in detection of titers for Salmonella agglutinins. A 0.5\% BSA concentration has been previously shown to enhance the titers for Salmonella O agglutinins in the passive haemagglutination assay (Coovadia et al., 1986), supporting the role for BSA as an enhancing agent in the detection of Salmonella agglutinins.

The role of BSA as an enhancing agent has already been documented under various settings. For example, Polymerase Chain Reaction (PCR) for DNA amplification is limited, in part, by the presence of inhibitors in biological samples that reduce the amplification efficiency. The addition of BSA to reaction mixtures of PCR has clearly been shown to decrease the inhibitory effect of blood and allow DNA amplification (Abu Al-Soud and Rådström, 2000). For the detection of Mycobacterium tuberculosis in respiratory specimens the presence of BSA in the PCR reaction has been regarded as mandatory (Forbes and Hicks, 1996). Similarly the presence 
of BSA in ELISA also eliminates interference resulting from the use of human, rat or mouse serum albumins in the assay (Pestka and Chu, 1984). These data along with the findings of this study highlight the role of BSA as an amplification facilitator, though the exact mechanism of action remains obscure.

Significantly high titers of Salmonella agglutinins both for $\mathrm{H}$ and $\mathrm{O}$ antigens were detected using the microplate agglutination assay compared with those detected by the Widal tube agglutination test when serum samples were absorbed with SRBCs. Using nonmotile Salmonella typhi organisms in a haemagglutination assay absorption of serum with SRBC has previously been shown to enhance the level of detection of $\mathrm{O}$ agglutinins, with no effect on detecting $\mathrm{H}$ agglutinins (Jesudason et al., 1991). On the basis of this finding antibody response against the non-flagellar proteins was proposed to be more important in Salmonella infection. In disagreement with this proposition it is possible that the use of non-motile Salmonella typhi organisms may have resulted in subsequent precipitation of non-flagellar proteins only. The enhancement of both $\mathrm{H}$ and $\mathrm{O}$ agglutinin titers observed in the present study could be due to the fact that commercially prepared suspensions of both $\mathrm{O}$ and $\mathrm{H}$ antigens were used. The findings of both studies, however, are consistent with regards to enhancement in the level of detection of Salmonella agglutinins when the sera were absorbed with SRBCs prior to being tested.

SRBCs in routine laboratory practice are used to detect heterophile antibodies. These antibodies are characteristically found in the sera of patients suffering from infectious mononucleosis, along with other clinical conditions, where the serum levels of heterophile antibodies have also been related to disease activity (Duverlie et al., 1989; Yoshida et al., 1980; Satoh et al., 1980; Moore and Dorner, 1980; Tamura et al., 1984). Since heterophile antibodies can be detected in an otherwise healthy population (Kakoma et al., 1987) their presence in the serum samples, sent to the laboratory for routine investigations and their ability to interfere with the results, cannot be ignored. There are no reliable data regarding heterophile antibodies in Salmonella infection. The findings of this study, however, provide indirect evidence that these antibodies could be present in the samples tested. The enhancement of titers and the percentage for Salmonella agglutinins, observed consequent to SRBC absorption, may be due to the depletion of heterophile antibodies in serum samples.

Heat inactivation was found to be associated with a decreased level of detection titers for Salmonella agglutinins. Using the indirect haemagglutination test, indirect fluorescent antibody test and enzyme-linked immunosorbent assay, heat inactivated serum samples yielding low titers of Salmonella agglutinins in patients with a confirmed diagnosis of typhoid fever has been reported in the past (Rai et al., 1989); this was attributed to partial antibiotic therapy prior to presentation. Since reduction in the titers of Salmonella agglutinins, both for $\mathrm{H}$ and $\mathrm{O}$ antigens was noticed uniformly in this study, heat induced protein denaturation appears to be the most likely cause. This is evident from the fact that heating mouse serum has been shown to cause a selective loss of immunoglobulin isotypes (Schetters et al., 1988). Alternatively this observation may indicate the presence of a thermolabile factor in the serum modulating antigen antibody interactions.

Conclusion. Findings of this study reveal that the novel modified microplate agglutination assay using the SRBC absorption technique, apart from being a useful alternative, performs better than the Widal tube agglutination test for the serological diagnosis of typhoid fever. It offers the advantages of simplicity, rapidity, economy and flexibility for handling a large numbers of specimens. This microplate assay appears to a useful assay not only for the detection of Salmonella infection but may be applied for diagnosis of other bacterial infections. This study was limited by relatively small number of patients investigations involving a larger group of patients are recommended to further evaluate the microplate assay.

\section{Literature}

Abu Al-Soud W. and P. Rådström. 2000. Effects of amplification facilitators on diagnostic PCR in the presence of blood, Feces, and Meat. J. Clin. Microbiol. 38: 4463-4470.

Bakr W.M., L.A. El Attar, M.S. Ashour and A.M. El Toukhy. 2011. The dilemma of widal test - which brand to use? a study of four different widal brands: a cross sectional comparative study. Ann. Clin. Microbiol. Antimicrob. 10-17.

Baker S., M. Favorov and G. Dougan. 2010. Searching for the elusive typhoid diagnostic. BMC Infect. Dis. 10: 45-52

Barrett TJ., P.A. Blake, S.L. Brown, K. Hoffman, J. Mateullort and J.C. Feeley. 1983. Enzyme linked immunosorbent assay for detection of human antibodies to Salmonella Vi antigen. J. Clin. Microbiol. 17: 625-627.

Barsoum IS. and A.Y. Awad. 1972. Microtitre plate agglutination test for Salmonella antibodies. Appl. Microbiol. 23: 42-50.

Chart H., B. Rowe and S.S. Cheesbrough. 1997. Serological response of patients infected with Salmonella typhi. J. Clin. Pathol. 50: 944-946. Chart H., D.J. Waghorn and B. Rowe. 1994a. Serological detection of patients infected with Salmonella enteritidis. Serodiagn Immunother Infect. Dis. 6: 79-81.

Chart H., D.J. Waghorn and B. Rowe. 1994b. Serological response of patients infected with Salmonella enteritidis PT4. Serodiagn Immunother Infect. Dis. 6: 21-24.

Choo K.E., A.R. Raazib, S.J. Oppenheimer, W.A. Ariffin, J. Lau and T. Abraham. 1993. Usefulness of the Widal test in diagnosing childhood typhoid fever in endemic areas. J. Paedia. Child. Health. 29: 36-39

Clegg A., M. Passey, M. Omena, K. Karigifa and N. Suve. 1994. Re-evaluation of the Widal agglutination test in response to the 
changing pattern of typhoid fever in the highlands of papua New Guinea. ACTA Tropica. 57: 255-263.

Coovadia YM., V. Sing, R.H. Bhana and N. Moodley. 1986. Comparison of passive haemagglutination test with Widal agglutination test for serological diagnosis of typhoid fever in an endemic area. J. Clin. Pathol. 39: 680-683.

Duthie R. and G.L. French. 1990. Comparison of methods for the diagnosis of typhoid fever. J. Clin. Pathol. 43: 863-865.

Duverlie G., M. Driencourt, C. Roussel and J. Orfila. 1989. Heterophile IgM, IgA, and IgE antibodies in infectious mononucleosis. J. Med. Virol. 28: 38-41.

Farooqui B.J., M. Khurshid, M. K. Ashfaq and M. A. Khan. 1991. Comparative yield of Salmonella typhi from blood and bone marrow cultures in patients with fever of unknown origin. J. Clin. Pathol. 44: 258-9.

Forbes B.A. and K.E. Hicks. 1996. Substances Interfering with Direct Detection of Mycobacterium tuberculosis in Clinical Specimens by PCR: Effects of Bovine Serum Albumin. J. Clin. Microbiol. 34: 2125-2128.

Ghosh K., K.N. Javeri, D. Mohanty, B.D. Parmar, R.R. Surati and S.H. Joshi. 2001. False positive serological tests in acute malaria. $B r$. J. Biomed. Sci. 58: 20-3.

Hoffman SL., T.P. Flanigan, D. Klaucke, B. Leksana, R.C. Rockhill, N.H. Punjabi, S.P. Pulungsih, A. Sutomo and M.A. Moechtar. 1986. Widal slide agglutination test, a valuable rapid diagnostic test in typhoid fever patients at the infectious diseases Hospital of Jakarta. Am. J. Epidemiol. 123: 869-875.

Jesudason MV., G. Sridharan, R. Arulselvan, P.G. Babu, PG and T.J. John. 1998. Diagnosis of typhoid fever by the detection of antiLPS and anti-flagellin antibodies by ELISA. Indian. J. Med. Res. 107: 204-7.

Jesudason MV., G. Sridharan, M. Santhossh and T.J. Lohn. 1991. Measuring antibody to non-flagellar proteins of Salmonella typhi for diagnosis of typhoid fever. Trans. R. Soci. Trop. Med. Hyg. 85: $117-118$.

Jindal N., I.B. Aggarwal, Arora. A and S. Arora. 1992. Diagnostic accuracy of IgM antibody detection in typhoid by a modification in Widal test. Indian. J. Med. Res. 95: 224-226.

Kakoma I., R.M. Mwendapole, M. Bulsara, S. Mabenga, C.S. Syabula and K.F. Wurapa. 1987. Profiles of heterophile antibody to various mammalian erythrocytes in rural populations of Zambia. Comp. Immunol. Microbiol. Infect. Dis. 10: 51-57.

Keddy KH., A. Sooka, M.E. Letsoalo, G. Hoyland, C.L. Chaignat and A.B. Moore TL. and R.W. Dorner. 1980. 19S IgM Forssmantype heterophile antibodies in juvenile rheumatoid arthritis. Arthritis. Rheum. 23: 1262-1267.

Morrissey, J.A. Crump. 2011. Sensitivity and specificity of typhoid fever rapid antibody tests for laboratory diagnosis at two sub-Saharan African sites. Bull. World. Health. Organ. 89: 640-647.
Nardiello S., T. Phizzella, M. Russo and B. Galanti. 1984. Serodiagnosis of typhoid fever by enzyme linked immunosorbent assay of anti-Salmonella typhi lipopolysaccharide antibodies. J. Clin. Microbiol. 20: 718-721

Omuse G., R. Kohli and G. Revathi. 2010. Diagnostic utility of a single Widal test in the diagnosis of typhoid fever at Aga Khan University Hospital (AKUH), Nairobi, Kenya. Trop. Doct. 40: 43-44. Pang T. and S.D. Putucheary. 1983. Significance and value of the Widal test in the diagnosis of typical fever in an endemic area. J. Clin. Pathol. 36: 471-475.

Parry C.M., T.T.H. Nguyen, D. To Song, W. John and T.C. Nguyen. 1999. Value of a single-tube Widal test in diagnosis of typhoid fever in Vietnam. J. Clin. Microbiol. 37: 2882-2886.

Pestka J.J. and F.S. Chu. 1984. Aflatoxin B1 dihydrodiol antibody: production and specificity. Appl Environ Microbiol. 47: 472-477.

Rai GP., K. Zachariah and S. Shrivastava. 1989. Comparative efficacy of indirect haemagglutination test, indirect fluorescent antibody test and enzyme linked immunosorbent assay in serodiagnosis of typhoid fever. J. Trop. Med. Hyg. 92: 431-434.

Saha S.K., M. Ruhulamin, M. Hanif, M. Islam and W.A. Khan. 1996. Interpretation of the Widal test in the diagnosis of typhoid fever in Bangladeshi children. Ann. Trop. Peadiatr. 16: 75-78.

Satoh PS., A.J. Elberg, W.E. Fleming, H.J. Baluarte and A.B. Gruskin. 1980. Heterophile antibodies in the serum of children with nephrotic syndrome. Vox. Sang. 39: 128-133.

Schetters T., J. Van Run-Van Breda, A. and W. Eling. 1988. Selective depletion of immunoglobulin isotypes after decomplementation of mouse sera by heat treatment. J. Immunol. Methods. 109: 193-197. Sharma M., U. Datta, P. Roy, S. Verma and S. Sehgal. 1997. Low sensitivity of counter-current immuno-electophresis for serodiagnosis of typhoid fever. J. Med. Microbiol. 46: 1039-1042.

Steinitz M. 2000. Quantitation of the blocking effect of tween 20 and bovine serum albumin in ELISA microwells. Anal. Biochem. 282: 232-238.

Tamura T., F. Merino, K. Kano, P. Ramirez-Duque and F. Milgrom. 1984. Heterophile antibodies in sera of patients with Chediak-Higashi syndrome. Int Arch Allergy Appl Immunol. 73: 186-188.

Verdugo-Rodriguez A., Y. Lopez-Vidal, J.L. Puente, G.M. RuizPlacios and E. Calva. 1993. Early diagnosis of typhoid fever by Enzyme Immunoassay using Salmonella typhi outer membrane protein preparation. Eur. J. Clin. Microbiol. Infect. Dis. 12: 248-254.

Wain J. and S. Hosoglu. 2008. The laboratory diagnosis of enteric fever. J. Infect. Dev. Ctries. 2: 421-5.

Yoshida H., N. Takeda, T. Nishimaki, T. Morito, R. Kasukawa, K. Kano and F. Milgrom. 1980. Heterophile antibodies in Japanese patients with various diseases including infectious mononucleosis. Immunol. Commun. 9: 403-408. 